\title{
Fen Bilgisi Öğretmen Adaylarının Genel Kimya Laboratuvarı Dersinde Aktif Öğrenmelerini Sağlamaya Yönelik Bir Eylem Araştırması*
}

\author{
Canan CENGİZ1
}

1Dr., Karadeniz.Teknik.Üniversitesi, cccanancengiz@gmail.com

\section{ÖZ}

Ortaokul öğrencilerinin kimya laboratuvar bilgi ve becerilerinin gelișimini sağlayan fen bilgisi öğretmenlerinin bu konuda yeterlilik sahibi olması önemlidir. Fakat araştırmacının Fen Bilgisi Öğretmenliği programında yürüttüğü Genel Kimya Laboratuvarı 1 ve 2 (GKL) derslerinde yaptığı bireysel gözlemler ve yapılan çalışmalar, öğretmen adaylarının laboratuvarda güçlük çektiklerini göstermiştir. Bu sebeple araştrrmacı GKL-1 dersinde gerçekleştirmek üzere eylem araştırması planlamıştır. Bu çalışmanın amacı GKL-1 dersinde fen bilgisi öğretmen adaylarının "laboratuvar malzemelerini tanıma, güvenlik kurallarına uyma ve çözelti hazırlama" gibi laboratuvar çalışmaları için gerekli olan temel konularda karşılaşıtıları güçlükleri yansıtıcı öğretime dayalı bir öğretim anlayışıyla aşmak ve öğretmen adaylarının derse aktif katılımını sağlamaktır. Bu amaçla araştırmacı bu konular ile ilgili yansıııı öğretime dayalı etkinlikler geliştirmiş ve 22 birinci sınıf fen bilgisi öğretmen adayına uygulamıştır. Öğretimin öğretmen adaylarının öğrenmeleri üzerindeki etkililiğini değerlendirmek amacıyla başarı testi ve ögretmen adaylarının etkinliklere yönelik görüşlerini belirlemek amacıyla uygulama sürecini değerlendirme anketi uygulanmıștır. Çalıșmadan elde edilen bulgular genel olarak öğretmen adaylarının etkinlikleri faydalı ve eğlenceli bulduklarını göstermiştir. Bununla birlikte öğretmen adaylarında genel olarak kalıcı öğrenme sağlanmış olsa da, çözelti hazırlamaya yönelik problem sorusunu cevaplayamadıkları tespit edilmiştir. Bu sonuca bağlı olarak, öğretmen adaylarının çözelti hazırlama problemlerine yönelik problem çözme süreçlerinin incelenmesi ve bu doğrultuda çözelti hazırlama problemlerine yönelik yeni bir etkinlik tasarlanması önerilmektedir.

Anahtar Kelimeler: Genel kimya laboratuvarı, fen bilgisi öğretmen adayları, yansıtıc öğretim, laboratuvarda güvenlik, çözeltiler

\section{An Action Research For Enabling Pre-Service Science Teachers' Active Learning in General Chemistry Laboratory Course}

\begin{abstract}
It is important for science teachers who develop chemistry laboratory knowledge and skills of middle school students are competent in pedagogies applied in laboratory. However, the researcher's personal observations as well as studies carried out in General Chemistry Laboratories 1 and 2 (GCL) courses have shown that pre-service science teachers have some difficulties in the laboratory. To address this issue, the researcher planned and implemented an action research in GCL-1 course. Thus, the aim of this study is to overcome the difficulties faced by the pre-service science teachers in the core subjects of chemistry laboratory such as "recognition of laboratory materials, safety rules, and solution preparation" in GCL-1 course by using reflective teaching approach. The researcher developed reflective teaching-related activities on the subjects and administrated them to 22 first-year pre-service science teachers. In order to evaluate the effectiveness of the teaching on the pre-service science teachers' learning, an achievement test was utilized. The participants' views about the activities and implementation process were determined by a questionnaire. Findings of the study have shown that the activities were useful and entertaining for the pre-service teachers. However, it has been noted that the participants cannot solve solution preparation problems regardless of their gains in the laboratory. Based on this result, it is suggested pre-service teachers' problem solving processes for solution preparation problems should be examined and a new activity for solution preparation problems should be design in this direction.
\end{abstract}

Keywords: General Chemistry Laboratory, pre-service science teachers, reflective teaching, laboratory safety rules, solution

* Bu çalışmanın kısa özeti; 12. Ulusal Fen Bilimleri ve Matematik Eğitimi Kongresi, 28-30 Eylül 2016, Trabzon'da sunulmuștur. 


\section{GİRİ̧̧}

Laboratuvar çalışmaları birçok fen programının temel taşıdır. Laboratuvarlar geleneksel sınıf ortamı ile kıyaslandığında etkileşime daha açıktır ve öğrencilerin öğrenmeye aktif katılımının sağlandı̆̆ı ortamlardır (Herrington \& Nakhleh, 2003). Öğrencilere işbirliği ve iletişim becerilerini geliştirme imkanı sağlama ve onların fene karşı pozitif tutum geliştirmeleri konusunda yardımcı olma potansiyeline sahiptir. Öğrencilerin kazanması hedeflenen kavram ve becerilere yönelik uygun etkinlikler tasarlandığında, laboratuvarda gerçekleşen öğretim, öğrencilere bilgiyi yapılandırmaları konusunda yardımcı olma, onların problem çözme, sorgulama ve psikomotor becerilerinin gelişimini sağlama konusunda etkilidir (Hofstein, 2004).

Fen bilgisi öğretmen adaylarının kimya laboratuvarına yönelik bilgi ve becerilerini lisans öğrenimleri süresince geliştirmeleri önemlidir. Çünkü bu süreçte edinecekleri bilgi ve beceriler mesleki yaşamlarında kimya laboratuvarında gerçekleştirecekleri öğretimin kalitesini belirleme konusunda temel oluşturacaktır (Ürey \& Aydın, 2014). Fakat yapılan bazı araştırmalar, öğretmen adaylarının laboratuvar uygulamalarına yönelik, içerik bilgisi eksikliği, uygulama bilgisi eksikliği ve özgüven eksikliği gibi bazı yetersizliklere sahip olduklarını göstermektedir (Coştu, Ayas, Çalık, Ünal \& Karataş, 2005; Feyzioğlu, Demirdağ, Ateş, Çobanoğlu \& Altun, 2011; Kocakülah ve Savaş, 2011; Özdem, Ertepınar, Çakıroğlu \& Erduran, 2013).

Fen bilgisi öğretmen adaylarının lisans öğrenimleri süresince kimya laboratuvarına yönelik bilgi ve becerilerini istenen düzeyde geliştirememeleri öğretimin karmaşık ve çok kollu bir yap1 içerisinde gerçekleşmesi ile açıklanabilir. Bu çevre profesörler, öğretmen adayları, öğretim elemanları, program, okul politikası ve beklentileri tarafından oluşturulur. Bu çevreyi ayrıca katılımcıların hisleri, düşünceleri ve eylemleri de etkiler. Bu karmaşık yapı ve bilgiyi yapılandırmanın kolay olmaması, öğretmen adaylarını sıklıkla anlamlı öğrenmeden ziyade ezbere yönlendirir (Nakhleh, 1994).

Fen bilgisi öğretmen adaylarının genel kimya laboratuvarı derslerinde anlamlı ve kalıcı öğrenmelerini sağlama konusunda öğretim sürecine üstbilişsel öğrenmeyi dahil etmek etkili bir yöntemdir. Üstbiliş, bilişsel süreçten farkl1lık gösterir. Biliş, herhangi bir konunun farkında olma ve onu anlama ile ilgilidir. Üstbiliş ise farkında olunan bu konunun nasıl öğrenildiğinin farkında olmayı içerir (Rickey \& Stacy, 2000; Senemoğlu, 2012). Üstbiliş, kişinin kendi düşünme süreçlerinin farkında olması, bu süreçleri kontrol edebilmesi, bilişini düzenleyebilmesi ve değerlendirebilmesi anlamına gelmektedir (Ersözlü ve Arslan, 2009; Özsoy, 2008). Etkili öğrenme ortamlarının oluşturulabilmesi bireylerin kendi öğrenme gereksinimlerinin, özelliklerinin ve öğrenme yollarının farkında olmasıyla olanaklıdır (Gündoğan Çögenli ve Güven, 2014). Öğrenme gerçekleşirken, öğrenme sürecinin gözlemlenerek, öğrenmeye yönelik bilginin (üstbilişsel bilgi) etkin hale getirilip, öğrenmenin düzenlenmesinde kullanılmasında yansıtma işlev görür (Ertmer \& Newby, 1996). Yansıtma, eylemlerimizi gerçekleştirdikten sonra onları değerlendirerek, düşüncelerimizi derinleştirmek, sistematik hale getirmek ve bu doğrultuda sonraki eylemlerimizi planlamayı içerir (Hatton \& Smith, 1995).

Öğrenme yazıları, yansıtıcı günlükler, kendini değerlendirme, sorgulama, zihin haritalama ve portfolyolar yansıtıcı uygulamalardan bazılarıdır (Cengiz, 2014). Yansıtıcı uygulamalar ile öğrenenlerin sadece ders kitaplarını okuyup, ögretmenin açıklamalarını takip etmelerinden ziyade, öğretmenleriyle ve akranlarıyla diyalog içerisinde olması, soru sorması, sorularının cevaplarını araştırması, derse katılım göstermesi ve akranlarına öğretmesi hedeflenir (URL 1). Böylelikle bu yaklaşım öğrenenleri, aktif öğrenmenin gerçekleşmesi ve öğrenmelerinden sorumluluk almaları konusunda destekler (Wilson \& Jan, 1993).

Araştırmacının, Fen Bilgisi Öğretmenliği programında altı sene boyunca yürütmüş olduğu Genel Kimya Laboratuvarı (GKL) derslerinde yaptı̆̆ı gözlemler doğrultusunda, öğretmen adaylarının çoğunun derse aktif olarak katılmadığı, "laboratuvar malzemelerini tanıma, güvenlik kurallarına uyma ve çözelti hazırlama" gibi temel konularda güçlük yaşadıkları belirlenmiştir. Buradan hareketle, bu çalışmada fen bilgisi öğretmen adaylarının GKL-1 dersinde daha aktif ve kalıcı öğrenmelerini sağlamak amacıyla yansıtıcı etkinliklerin geliştirilmesi ve uygulanmasına yönelik bir eylem planlanmştır.

Bu çalışmanın amacı GKL-1 dersinde fen bilgisi öğretmen adaylarının "laboratuvar malzemelerini tanıma, güvenlik kurallarına uyma ve çözelti hazırlama” gibi laboratuvar çalışmaları için gerekli olan temel konularda 
karşılaştıkları güçlükleri yansıtıcı ögretime dayalı bir öğretim anlayışıyla aşmak ve öğretmen adaylarının aktif ve kalıcı ögrenmelerini sağlamaktır. Bu amaçla bu çalışmada aşağıda yer alan araştırma sorularına cevap aranmıştır:

- Yansıtıcı öğretime dayalı olarak gerçekleştirilen öğretim sonucunda etkili öğrenme gerçekleşmiş midir?

- Öğretmen adaylarının gerçekleştirilen öğretime yönelik görüşleri nelerdir?

\section{YÖNTEM}

Çalışma eylem araştırması bakışıyla tasarlanmış ve yürütülmüştür. Eylem araştırması, akademisyenlerin kendi öğretim uygulamalarını, öğrencilerinin öğrenmelerine ve programa yönelik problemlerine ilişkin işbirlikçi bir yaklaşım ile sorgulamalarıdır (Zuber-Skerritt, 1992). Eylem araştırmaları, araştırma ve pratik uygulamayı eşzamanlı olarak bir tek etkinlikte toplamaktadır. Her ne kadar tüm araştırmalar, mülakat yapma, anketlerin dağıtımı gibi eylemler içerse de, eylem araştırmalarında sözü geçen eylem daha farklı bir anlam taşımaktadır. Sosyal bir araştırma türü olan eylem araştırmaları, profesyonel, organizasyonel bir eylem veya bir topluluğa yönelik eylemde, değişim sürecinde yer alan bireyi ele alır ve eylem sonucunda öğrenmenin gerçekleşmesini amaçlar (Winter \& Munn-Giddings, 2002).

Eylem araştırmaları bazı yönleri ile diğer sosyal araştırmalardan ayrılmaktadır. Öncelikle eylem araştırmasının asıl amacının uygulamayı iyileştirmek olduğu söylenebilir. Bu sebeple bilgi üretmek, eylem araştırmasının öncelikleri arasında yer almaktadır. İkinci olarak eylem araştırması ile ilk elden öğrenme gerçekleşmektedir çünkü bu araştırma türü uygulamayı yapan bireylerin araştırma sürecine doğrudan katılımını sağlamaktadır. Üçüncü olarak eylem araştırmaları gerçek dünya içerisinde yürütülür ve var olan sorunları çözmeyi amaçlamaktadırlar. Dördüncü olarak, eylem araştırmaları bireylerin doğrudan katılım yoluyla güçlenmesini, işbirliğinin ve sosyal değişimin gerçekleşmesini sağlamaktadır. Son olarak da ulaşılan çözümler araştırmaya doğrudan katılım sonucunda gerçekleştiği için bu çözümlerin uygulamaya aktarılma sürecinde direnç yaşanmamaktadır (Aksoy, 2003).

Bu çalışmada Collins ve Spiegel'in (1995) tanımladığı dört aşamalı eylem araştırması deseni takip edilmiştir. Aşağıda aşamalar ve her bir aşamada gerçekleştirilmesi beklenen eylemler ile ilgili bilgi verilmiş ve takip eden paragrafta bu çalışmada gerçekleştirilen eylemler açılanmıştır.

1. Problemin Tanımlanmas 1

Eylem araştırmaları araştırmacı öğretmen tarafindan, sınıf uygulamaları üzerine gerçekleştirilen yansıtmalar ile başlamaktadır. Örneğin öğretmen kullanacağ1 yeni bir öğretim stratejisinin öğrenci başarısı üzerindeki etkililiğini merak edebilir. Bu noktada dikkat edilmesi gereken konu, belirlenen problemin öğretmenin değiştirmeye gücünün yeteceği nitelikte olmasıdır. (Collins \& Spiegel, 1995).

Bu çalışmada, araştırmacı öğretmen alt1 yıllık deneyimi süresince Fen Bilgisi Öğretmenliği bölümünde yürüttüğü GKL derslerinde öğretmen adaylarının çoğunun derse aktif olarak katılmadığı, "laboratuvar malzemelerini tanıma, güvenlik kurallarına uyma ve çözelti hazırlama” gibi temel konularda güçlük yaşadıklarını belirlemiş ve bu sorunu çözmeye yönelik bir çalışma yapmaya karar vermiştir.

2. Plan Yapma

Bu basamakta, belirlenen problemin çözümüne yönelik bir plan yapılmaktadır. Belirlenen plan, araştırma yöntemleri ile uyumlu olmalı ve araştırmada uygun araçlar kullanılmalıdır (Collins \& Spiegel, 1995).

Çalışmada, GKL-1 dersinde yansıtıcı uygulamalardan yararlanmanın öğretmen adaylarının aktif ve kalıcı öğrenmelerinde etkili olacağ1 düşünülmüştür. $\mathrm{Bu}$ amaçla araştırmac1 öğretmen "güvenlik önlemlerini öğrenelim,” “malzemeleri tanıyalım," "çözelti hazırlayalım-I," “çözelti hazırlayalım-II” isimli yansıtıcı öğretime dayalı dört etkinlik geliştirmiştir. Öğretmen adaylarının ders sürecinde portfolyo hazırlamalarına karar verilmiştir. Veri toplama aracı olarak araştırmacı günlüğü, başarı testi ve uygulama sürecini değerlendirme anketi kullanılmıştır. 
3. Planlar1 Uygulama

Plan yapıldıktan sonra planın uygulaması gerçekleştirilir. Plan, her ne kadar iyi tasarlanmış olsa da araştırma sürecinde üzerinde değişiklikler yapılabilmektedir. Bu süreçte öğretmenin topladığı bilgileri dikkatlice incelemeye zaman ayırması önemlidir (Collins \& Spiegel, 1995).

Bu çalışma toplam yedi hafta (14 saat) sürmüştür. Araştırmacı her bir etkinliği, etkinliğin gerçekleştirileceği haftadan bir hafta önce hazırlamıştır. Etkinlik gerçekleştirildikten sonra araştırmacı, öğretimine dayalı olarak günlük tutmuş ve bu doğrultuda bir sonraki haftanın etkinliğini hazırlamıştır. Başarı testi, öğretmen adaylarının öğrenmelerinin etkililiğini ve kalıcıllğııı belirleyebilmek amacıyla dönemin son dersinde uygulanmıştır.

4. Uygulama Sürecinin Değerlendirilmesi

Eylem tamamlandığında eylem üzerine yansıtma yapılır ve eylem değerlendirilir. Öğretmen bu aşamada kendisine şu sorular1 sorabilir: "Uygulama, öğrencilerim üzerinde ne gibi değişikliklere sebep oldu?, Öğrencilerim ile ilgili olarak ne öğrendim?, Öğrenmeye yönelik ne öğrendim?, Öğrendiklerim doğrultusunda hangi konuda yeni bir araştırma yapmak isterim?"

Bu çalışmada da uygulama süreci sonunda, elde edilen veriler analiz edilerek, geliştirilen etkinliklerin öğretmen adaylarının aktif ve kalıcı öğrenmeleri üzerindeki etkililiği değerlendirilmiştir. Öğretmen yansıtmaları doğrultusunda, sonraki uygulamalarda etkinliklerin daha etkili olmasını sağlamak amacıyla bazı önerilerde bulunulmuştur. Ayrıca yeni araştırma önerileri sunulmuştur.

\section{1. Örneklem}

Bu çalışmanın örneklemini Fen Bilgisi Öğretmenliği birinci sınıfta öğrenim görmekte olan 17'si kız, 5’i erkek toplam 22 öğretmen adayı oluşturmaktadır. Uygulama öncesinde yapılan bir ankete öğretmen adaylarının verdiği cevaplar doğrultusunda bu çalışmaya katılan 22 öğretmen adayından 18'inin lisede gördükleri kimya dersleri süresince, kimya laboratuvarında hiç ders işlemedikleri belirlenmiştir.

\section{2. İşlem Süreci}

2015-2016 güz yarıyllında gerçekleştirilen uygulama toplam beş hafta yani on ders saati sürmüş, çalışma ise yedi haftada tamamlanmıstır. Dersler bu çalışmanın yazarı olan kimya eğitimi alanında doktorasını tamamlamış bir araştırmacı ve fen bilgisi eğitimi alanında doktora yapmakta olan bir araştırma görevlisi tarafından yürütülmüştür. Şekil 1'de işlem süreci özetlenmiştir:

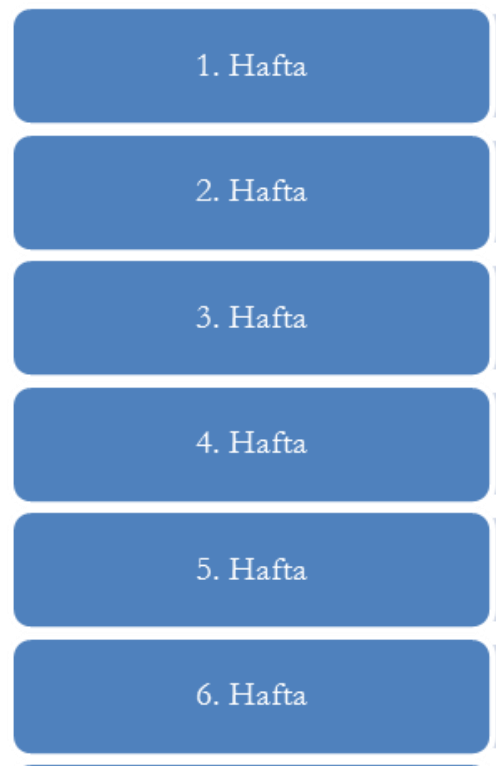

14. Hafta

\begin{tabular}{|c|}
\hline $\begin{array}{l}\text { - Öğretmen Adaylarının Bilgilendirilmesi } \\
\text {-Ders içeriği/derslerin ișleniși/performans } \\
\text { değerlendirme/ödev ve sorumluluklar }\end{array}$ \\
\hline $\begin{array}{l}\text { •Yansitıcı Uygulamalar } \\
\text { •"Güvenlik önlemlerini öğrenelim" etkinliğinin } \\
\text { yapılması ve öğretmen yansıtmaları }\end{array}$ \\
\hline $\begin{array}{l}\text { - Yansitıcı Uygulamalar } \\
\text { - "Malzemeleri tanıyalım" etkinliğinin yapılması ve } \\
\text { öğretmen yansitmaları }\end{array}$ \\
\hline $\begin{array}{l}\text { - Yansitıc1 Uygulamalar } \\
\text { - "Çözelti hazırlayalım-I" etkinliğinin yapılması ve } \\
\text { öğretmen yansitmaları }\end{array}$ \\
\hline $\begin{array}{l}\text {-Yansitıcı Uygulamalar } \\
\text { •"Çözelti hazırlayalım-II" etkinliğinin yapılması ve } \\
\text { öğretmen yansıtmaları }\end{array}$ \\
\hline $\begin{array}{l}\text { - Öğretmen Adaylarının Görüşlerinin Belirlenmesi } \\
\text {-Uygulama sürecini değerlendirme anketi }\end{array}$ \\
\hline
\end{tabular}

- Öğrenmenin etkililiğinin ve kalıcılığının belirlenmesi

- Başarı testinin uygulanması

Şekil 1'den görüldüğü üzere uygulamanın ilk haftası öğretmen adaylarına GKL-1 dersinin içeriği, derslerin nasıl işleneceği, değerlendirmenin nasıl yapılacağı ve dönem ödevleri hakkında bilgi verilmiştir. Öğretmen adaylarına dönem boyunca portfolyo hazırlayacakları belirtilmiş ve portfolyoların içeriğinin nelerden oluşacağı konusunda kendileri bilgilendirilmiştir. 
Sonraki dört hafta sırasıyla laboratuvar güvenliği, laboratuvar malzemeleri, çözelti hazırlama I ve çözelti hazırlama II isimli etkinlikler gerçekleştirilmiştir. Geliştirilen etkinliklerin özetleri Tablo 1, Tablo 2, Tablo 3 ve Tablo 4'te sunulmuştur.

Altıncı hafta ise öğretmen adaylarının GKL-1 derslerinde gerçekleştirilen etkinliklere yönelik görüşlerini belirlemek amacıyla, kendilerine uygulama sürecini değerlendirme anketi uygulanmıştır. Uygulanan dört etkinliğin konularına yönelik öğretmen adaylarının başarılarını belirlemek amacıyla açık uçlu sorulardan oluşan başarı testi dönemin son dersinde (13. Hafta) uygulanmıştır. Altı-13. Haftalar süresince GKL'de farklı konulara yönelik, yansıtıcı öğretime dayalı etkinlikler/deneyler yapılmaya devam etmiştir. Başarı testinde yer alan sorular ilk dört etkinlik konusuna ilişkin olmasına rağmen, dönemin son dersinde uygulanmasının sebebi, öğrenmenin ne derece kalıcı olduğu hakkında da bilgi edinebilmektir.

Bu çalışma için hazırlanan etkinlikler Wilson \& Jan'ın (1993) yansıtıcı uygulamaları planlamak için önerdiği altı basmaktan oluşan tasarıma göre planlanmıştır. Aşağıda bu tasarıma ait her bir basamak ve bu basamakların amacı sunulmuştur:

Hazırlık aşaması: Bu basamağın amacı öğrencilerin temel etkinliğe hazır olmalarını sağlamaktır. Bu amaçla öğrencilerin önbilgileri belirlenir, öğrenme ihtiyaçları ve ilgileri tespit edilir ve sonraki basamakları planlamak için çizilecek yol belirlenir.

Temel Odaklanma Deneyimi: Bu basamağın amacı öğrencilerin başlangıçta sordukları sorulara cevap vermek, konu ile ilgili farklı sorular üretmelerini sağlamak, konuya ilgi çekmek ve öğretmen ve öğrencilerin bilgilerini genişleteceği ortak bir deneyim yaşamalarını sağlamaktır.

Verileri Organize Etmek ve Sunmak: Bu basamağın amacı öğrencilerin elde ettikleri bilgiyi analiz etmelerini, yorumlamalarını ve elde edilen bilgiyi farklı şekillerde organize ederek sunmalarını sağlamaktır.

Başka Etkinlikler ve Deneyimler: Bu basamağın amacı konunun genişletilmesine firsat sağlamak, konu ile ilgili daha fazla bilginin toplanmasını sağlamak ve öğrencilerin konu ile ilgili tartışmalarını sağlamaktır.

Yansıtma ve Eylem: Bu bölüm etkinlik süresince gerçekleşmelidir. Burada amaçlanan, elde edilen bilgi, beceri, değer veya tutumları pratikte uygulamak, gelecek deneyimleri planlamak ve yansıtıcı ve üstbilişsel davranışları izlemektir.

Tablo 1'de bu basamaklara uygun olarak geliştirilen ve uygulanan dört etkinlikten ilkinin özeti yer almaktadır:

Tablo 1. Güvenlik önlemlerini öğrenelim etkinliği

\begin{tabular}{|c|c|}
\hline Etkinlik Ad1 & Güvenlik Önemlerini Öğrenelim \\
\hline Hazırlık Aşaması & $\begin{array}{l}\text { Öğretmen adaylarına bil-iste-öğren tabloları dağttllır ve } \\
\text { bil ve iste bölümlerini doldurmaları istenir. }\end{array}$ \\
\hline Temel Odaklanma Deneyimi & $\begin{array}{l}\text { Öğretmen adayları gruplara ayrılarak, her bir gruba farklı } \\
\text { çalş̧ma kağıtları dağttıllı. Öğretmen adaylarında çalışma } \\
\text { kağıtlarında yer alan bilgileri okumaları istenir. }\end{array}$ \\
\hline Verileri Organize Etmek ve Sunmak & $\begin{array}{l}\text { Gruplar çalışma kağttlarında yer alan bilgileri kullanarak } \\
\text { poster hazırlar ve posterlerini sınıfa sunarlar. }\end{array}$ \\
\hline Başka Etkinlikler ve Deneyimler & $\begin{array}{l}\text { Gruplardan çalşma kağıtlarını birbirleriyle değiştirip } \\
\text { okumaları istenir. }\end{array}$ \\
\hline Yansitma ve Eylem & $\begin{array}{l}\text { Öğretmen adaylarından bil-iste-öğren tablosunun öğren } \\
\text { bölümünü bireysel olarak doldurmaları istenir. }\end{array}$ \\
\hline Öğretmen Değerlendirmesi ve Planlama & Araştırmacı öğretmen yansıtıcı günlük tutar. \\
\hline
\end{tabular}

Tablo 2'de geliştirilen ve uygulanan dört etkinlikten ikincisinin özeti yer almaktadır:

Tablo 2. Malzemeleri tanıyalım etkinliği

\begin{tabular}{ll}
\hline Etkinlik Adı & Malzemeleri Tanıyalım \\
\hline Hazırlık Aşaması & $\begin{array}{l}\text { Öğretmen adaylarına "deney tüpü patlaması" haberinin } \\
\text { bulunduğu kağıtlar dağıtılır ve okumaları istenir. }\end{array}$ \\
\hline Temel Odaklanma Deneyimi & Öğretmen adaylarına laboratuvar malzemeleri tanıtılır. \\
& Öğretmen adaylarının soruları varsa paylaşmaları istenir. \\
\hline Verileri Organize Etmek ve Sunmak & Öğretmen adaylarından laboratuvarı gezerek, \\
& laboratuvar malzemelerini incelemeleri ve malzemelerin \\
& şeklini kartonlara çizmeleri fakat malzemelerin isimlerini \\
& karton üzerine yazmamaları istenir (Her bir malzemeyi \\
& numaralandırmaları ve malzemelerin ismini ayrı bir \\
& kağı yazmaları istenir böylece resimli bir test \\
& hazırlamış olurlar). \\
\hline Başka Etkinlikler ve Deneyimler & Öğretmen adaylarının hazırladıkları resimli testleri \\
& arkadaşları ile değiştirmeleri ve arkadaşlarının çizmişş \\
\hline
\end{tabular}


olduğu laboratuvar malzemelerini adlandırmaları istenir. Öğretmen adaylarına laboratuvar malzemeleri ile ilgili resimli testlerini hazırlamadan önce laboartuvar malzemelerinden hangilerini tanıyı, hangilerini tanımadıklarını sormaları, analizlerini not etmeleri istenir. $\mathrm{Bu}$ şekilde öz-değerlendirme yaptıktan sonra resimli testlerini hazırlarlar (bu basamak verileri organize etme ve sunma basamağından önce gerçekleştirilmiştir).

Ögrretmen Değerlendirmesi ve Planlama Araştırmacı öğretmen yansıtıcı günlük tutar.

Tablo 3’te geliştirilen ve uygulanan dört etkinlikten üçüncüsünün özeti yer almaktadır:

Tablo 3. Çözelti hazırlayalım-I etkinliği

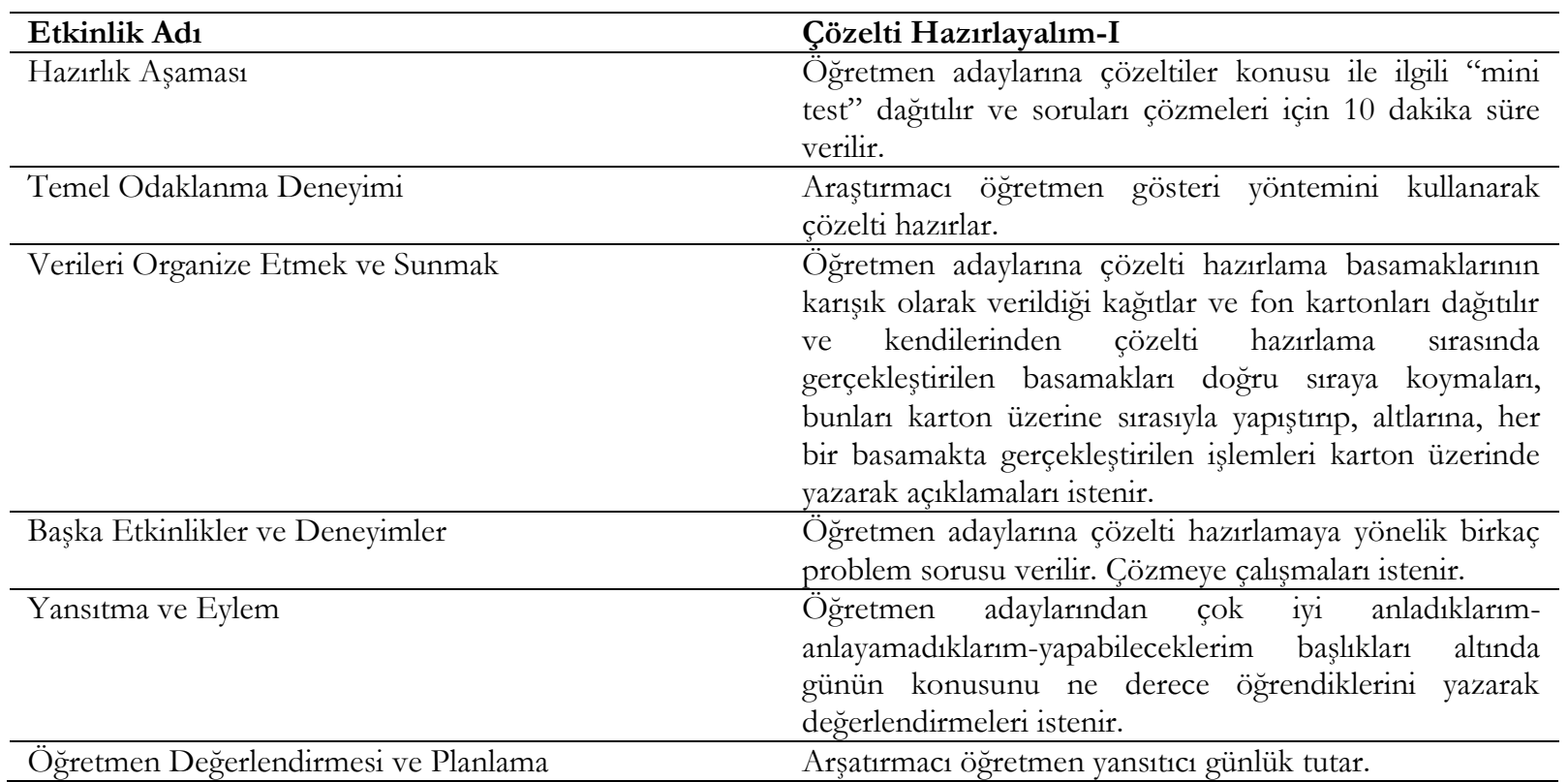

Tablo 4'te geliștirilen ve uygulanan dört etkinlikten dördüncüsünün özeti yer almaktadır:

Tablo 4. Çözelti hazırlayalım-II etkinliği

\begin{tabular}{|c|c|}
\hline Etkinlik Adı & Çözelti Hazırlayalım-II \\
\hline Hazırlık Aşaması & $\begin{array}{l}\text { Öğretmen adaylarına molarite ve normalite kavramlarını } \\
\text { sorulur. Ardından } 0,4 \mathrm{M} 1 \text { litre } \mathrm{NaCl} \text { çözeltisini nasıl } \\
\text { hazırlayacaklarını boş bir A4 kağıdının yarısını kullanarak } \\
\text { yazmaları istenir. ( } \mathrm{NaCl}: 58,5 \mathrm{~g} / \mathrm{mol})\end{array}$ \\
\hline Temel Odaklanma Deneyimi & $\begin{array}{l}\text { Sınıfça soru çözümlenir. Ardından şu soru yöneltilir: } \\
\text { Kütlece \%30’luk } 1,18 \mathrm{~g} / \mathrm{ml} \text { yoğunluğa sahip } \mathrm{HCl} \\
\text { çözeltisinden, 1lt } 1 \mathrm{M} \mathrm{HCl} \text { çözeltisi nasıl hazırlanır? } \\
\text { Öğretmen adaylarına düşünmeleri için firsat verilir, } \\
\text { ardından soru birlikte çözümlenir. }\end{array}$ \\
\hline Verileri Organize Etmek ve Sunmak & $\begin{array}{l}\text { Öğretmen adaylarına, her iki sorunun cevabını ayrıntılı } \\
\text { bir şekilde yazmaları için kağıtlar dağıtılır. }\end{array}$ \\
\hline Başka Etkinlikler ve Deneyimler & $\begin{array}{l}\text { Bu sırada gruplar teker teker çeker ocağın başına alınır. } \\
\text { Araştırmacı öğretmenin rehberliğinde, öğretmen adayları } \\
\text { grupça çözelti hazırlarlar. }\end{array}$ \\
\hline Yansitma ve Eylem & $\begin{array}{l}\text { Öğretmen adaylarından öğrenmeleri üzerine düşünerek, } \\
\text { bir sonraki dersin ilk saatinde ne yapılabileceği ile ilgili } \\
\text { fikirlerini not kağıtlarına yazmaları istenir. }\end{array}$ \\
\hline Öğretmen Değerlendirmesi ve Planlama & Araştırmacı öğretmen yansıtıcı günlük tutar. \\
\hline
\end{tabular}

\subsection{Veri Toplama Araçları ve Veri Toplama Araçlarının Geçerlilik ve Güvenirlik Çalışmaları}

$\mathrm{Bu}$ çalışmanın veri toplama araçlarını uygulama sürecini değerlendirme anketi, başarı testi ve araştırmacı günlüğü oluşturmaktadır.

2.3.1. Uygulama Sürecini Değerlendirme Anketi (USDA): Laboratuvarda gerçekleştirilen yansıtıcı öğretim uygulamalarının değerlendirilmesi amacıyla uygulama sürecini değerlendirme anketi hazırlanmıştır (Bkz. Ek 1). USDA, Aslan'ın (2015) çalışmasında kullanmış olduğu Deneyim Belirleme Testi’nden bu çalışma için uyarlanmıştır. Öğretmen adaylarının gerçekleştirilen uygulamalara yönelik deneyimlerini yansıtabileceği düşünülen dokuz olumlu (düşündürücü, eğlenceli vb.) ve yedi olumsuz (faydasız, gereksiz vb.) kelime kağıt üzerinde bir tablo içerisine yerleştirilmiş ve öğretmen adaylarından etkinlikleri tanımladığını düşündükleri kelimeleri seçmeleri ve seçme sebeplerini belirtmeleri istenmiştir. USDA kimya eğitimi alanında uzman olan bir öğretim üyesine incelettirilerek, görüşleri doğrultusunda ankete son hali verilmiştir. 
2.3.2. Başarı testi: Başarı testi araştırmacı tarafından öğretmen adaylarının öğrenmelerini değerlendirmek amacıyla geliştirilmiştir (Bkz. Ek 2). Başarı testinin kapsam ve yapı geçerliliğinin arttırılması amacıyla sorular biri kimya eğitimi alanında uzman olan bir öğretim üyesine ve diğeri fen bilgisi eğitimi alanında uzman olan bir araştırma görevlisine incelettirilmiş ve önerileri doğrultusunda sorulara son hali verilmiştir. Başarı testinde laboratuvar güvenliği, laboratuvar malzemeleri ve çözelti hazırlama ile ilgili birer açık uçlu soru bulunmaktadır. Sırasıyla sorular dört, altı ve iki alt sorudan oluşmaktadır.

2.3.3. Araştırmacı Günlüğü: Araştırmacı her bir etkinlikten sonra günlük tutarak, sınıf içi gözlemlerini not almış ve öğretimine yönelik yansıtma yapmıştır.

\subsection{Verilerin Analizi}

$\mathrm{Bu}$ bölümde, çalısmada kullanılan veri toplama araçları olan uygulama sürecini değerlendirme anketi, başarı testi ve araştırmacı günlügünden elde edilen verilerin analizi ile ilgili bilgi verilmiştir.

2.4.1. Uygulama Sürecini Değerlendirme Anketinden (USDA) Elde Edilen Verilerin Analizi: Araştırmanın nitel veri toplama araçlarından olan USDA'dan elde edilen verilerin analizinde öğretmen adayları tarafindan seçilen her kelime için frekans değerlerini içeren bir tablo oluşturulmuştur. Ayrıca öğretmen adaylarının bu kelimeleri seçme nedenlerini açıklayan ifadelerine yer verilmiştir.

2.4.2. Başarı Testinden Elde Edilen Verilerin Analizi: Başarı testinde yer alan üç soru toplam 12 alt sorudan oluşmaktadır. Testten alınabilecek maksimum puan 24’tür. Başarı testinin puanlandırılmasında izlenecek yolun belirlenmesi amacıyla, çalışmanın yazarı, öğretmen adaylarının sorulara verdikleri cevapları kimya eğitimi alanında uzman bir öğretim üyesi ile birlikte incelemiş ve değerlendirmiştir. Değerlendirmeler sonucunda herbir alt sorunun doğru cevap (2 puan), kismen doğru cevap (1) ve yanlış/boş (0) olmak üzere puanlandırılmasına karar verilmiştir. Puanlamalar yapıldıktan sonra her bir soru için toplam puan hesaplanmış ve öğretmen adaylarının konulardaki başarılarını karşılaştırabilmek amacıyla her bir soru için yüz üzerinden puanları hesaplanmışır.

2.4.3. Araştırmacı Günlüğünden Elde Edilen Verilerin Analizi: Araştırmacı günlükleri betimsel olarak analiz edilmiş ve diğer bulgular ile karşılaştırmalı olarak sunulmuştur.

\section{BULGULAR}

Çalışmanın bu bölümünde veri toplama araçlarından elde edilen bulgular iki alt başlık halinde sunulmuştur. Bunlar başarı testinden elde edilen bulgular ve uygulama sürecini değerlendirme anketinden elde edilen bulgulardır.

\subsection{Başarı Testinden Elde Edilen Bulgular}

Tablo 5'te öğretmen adaylarının her bir sorudan alabilecekleri maksimum ve minimum puanlar ve her bir sorudan aldıkları ortalama puanlar verilmiştir. Başarı testinde yer alan sorulardan (farklı konulara/etkinliklere yönelik) alınabilecek maksimum puanlar farklılık göstermektedir. Bu sebeple herbir soru için ortalama puanlar yüz üzerinden hesaplanmış ve öğretmen adaylarının farklı etkinliklere yönelik sorulardan aldıkları puanlar karşılaştırılmıştır.

Tablo 5. Öğretmen adaylarının bașarı testinden aldıkları puanlar

\begin{tabular}{llccc}
\multicolumn{4}{l}{ Tablo 5. Öğretmen adaylarının başarı testinden aldıkları puanlar } \\
\hline Soru No & Soru İçeriği & $\begin{array}{c}\text { Min-Mak } \\
\text { Puan }\end{array}$ & Ort & \% Ort \\
\hline 1 & Laboratuvar Malzemeleri & $0-12$ & 8,9 & 74,2 \\
\hline 2 & Laboratuvarda Güvenlik & $0-8$ & 3,5 & 43,8 \\
\hline 3 & Çözelti hazırlama & $0-4$ & 0,5 & 12,5 \\
\hline & Toplam & $0-24$ & 12,9 & 53,8 \\
\hline
\end{tabular}

Tablo 5’ten de görüleceği gibi öğretmen adayları testten ortalama olarak 24 puan üzerinden 12,9 puan $(\% 53,8)$ almışlardır. Öğretmen adaylarının en yüksek başarıyı laboratuvar malzemelerinin tanınmasına yönelik sorudan elde ettikleri belirlenmiştir $(\% 74,2)$. Laboratuvarda güvenliğe yönelik soruda ise öğretmen adaylarının kısmen başarılı oldukları görülmektedir $(\% 43,8)$. Çözelti hazırlama problemi olan son soruda ise öğretmen adayları en düşük başarıyı sergilemişlerdir $(\% 12,5)$.

Öğretmen adayları laboratuvar malzemelerinin tanınmasına yönelik hazırlanmış olan soruda en yüksek başarıyı elde etmişlerdir. Tablo 2'de öğretmen adaylarının laboratuvar malzemelerini tanıma ve işlevlerini 
öğrenmelerine yönelik hazırlanan etkinlik yer almaktadır. Etkinlik gerçekleştirildikten sonra araştırmacının (öğretmenin) tuttuğu günlükte yer alan bazı ifadeler şu şekildedir:

"Ögretmen adaylarna föylerinde yer alan her bir laboratuvar malzemesini tanttıktan sonra föylerini kapatmalarm, laboratuvarda gezerek laboratuvar malzemelerini kesfetmelerini ve kendilerine verilen süre içerisinde çizebildikleri kadar çok malzemeyi kartonlara çizmelerini istedim. Laboratuvarda gezinmeye, malzemeleri kesfetmeye basladılar. Bazlarmm daha fazla merakh olduğunu fark ettim. Föyde yer almayan ama laboratuvarda bulunan malzemeleri bulup, ismini ve işlevlerini sordular. Etkinliğin öğretmen adaylarmm hem malzemeleri tanmalarna hem de laboratuvara aşinalık kaz̧anmalarna yardımo olduğunu düs̈̈̈nüyorum.”

Laboratuvarda güvenlik ile ilgili soruyu ise öğretmen adaylarının yarısına yakınının cevaplayabildiği belirlenmiştir. Tablo 1'de öğretmen adaylarının laboratuvarda dikkat edilmesi gereken güvenlik önlemlerini öğrenmelerine yönelik geliştirilen etkinliğin özeti yer almaktadır. Bu etkinliğe ilişkin araştırmacı öğretmenin günlüğüne tuttuğu notlardan bazıları şöyledir:

"Laboratwvarda dikkat edilmesi gereken güvenlik kurallarm ögrenmeleri amacylla dörderli gruplardan olusan

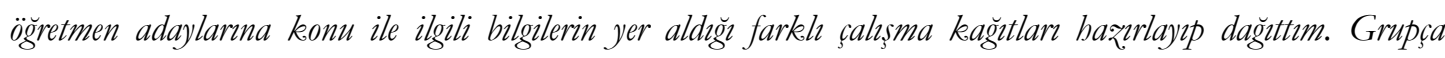
çalısarak, çalşsma kağtlarnndaki bilgileri görsel hale getirmeleri için kendilerine kartonlar ve boya kalemleri verdim. Her bir grup poster olusturdu ve diğgr gruplara sunum yaptı. Posterler olusturulurken tüm ögrretmen adaylarmm aym çabayı sergilemediğini fark ettim. Baz̧lar daha faz̧la çalşst. Bilgileri posterde görsel bale getirmeyi bazı ögretmen adaylar zevkli buldu, bazılar ise ilgisiz, davrand. Sunum yaparak bilgilerin

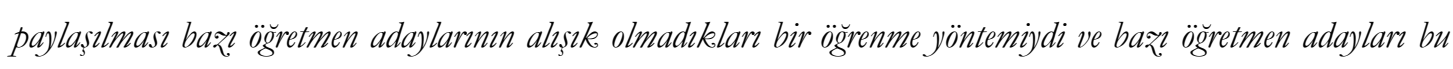
konuda çekingen davrandılar. Bažlar ise grup sözciüsü olma konusunda gönüllü davrandi. Belki sunum yapmaya dayah etkinlik dönemin daba ilerleyen zamanlarnda yapılmıs olsaydı daba iyi sonuclar verebilirdi. Öğretmen adaylar henüz öğrenme ortamına yabancu olduklar için sunum yapma konusunda biraz gekingen davrandilar. Kendilerini değerlendiriliyor gibi hissetmis olabilirler.”

Öğretmen adaylarının en az doğru cevaplayabildikleri soru ise çözelti hazırlama ile ilgili olandır. Öğretmen adaylarına sıvı-sıvı çözelti hazırlama ile ilgili bir problem sorusu yöneltilmiş ve çözeltiyi nasıl hazırlayacakları sorulmuştur. Öğretmen adayları içerisinde probleme doğru cevap veren olmamışken bazı öğretmen adayları çözelti hazırlamaya yönelik basamakları doğru olarak sunabilmişlerdir. Çözeltilerin hazırlanmasına yönelik iki farklı etkinlik hazırlanmıs ve uygulanmıstır (Bkz. Tablo 3 ve Tablo 4). İlk etkinlikte gösteri yöntemi kullanılarak çözelti hazırlanmış, ardından öğretmen adaylarına çözelti hazırlanmasına yönelik basamaklardan oluşan resimler karışı olarak dağıtılmış ve bunları bir sıraya koyarak, kartonlara yapıştırmaları ve altlarına işlemleri açıklamaları istenmiştir. Bu sürece yönelik olarak araştırmacı öğretmen günlüğ̈ne şunları not etmiştir:

"Bütün sinnf derse motive oldu ve görevlerini yerine getirdi. Tüm ögretmen adaylarnnn tek tek çözelti hažrlamalar için zamann yetmeyeceği dikkeate alindiğznda bu yöntemin yararl olduğu söylenebilir. Simf yönetimini sağlamada güclük yaşamadim çünkü ögretmen adaylar işleriyle mesguldüler ve simffta herbangi

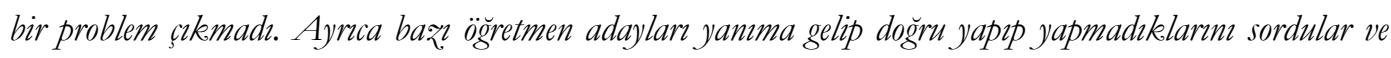
bazılar etkinliği zevkli bulduklarm belirttiler. Bununla birlikte bazı ögretmen adaylar kendilerinin ne zaman deney yapacağmm, bu konuda istekli olduklarm belirttiler. Bu durumu dikkate alarak bir sonraki etkinliği planlayacağım. $\ddot{U}_{\zeta}$ bafta süresince ögretmen adaylar deney yapmadıklar için artık sabırsızlandilar."

Dördüncü etkinlikte öğretmen adaylarına kat1-sıv1 ve s1v1-sıv1 çözeltilerin hazırlanmasına yönelik hesaplamalar anlatılmış ve öğretmen adayları gruplar halinde çözelti hazırlamışlardır. Bu etkinliği gerçekleştirdikten sonra araştırmacı öğretmenin günlüğüne tuttuğu bazı notlar şöyledir: "Bu

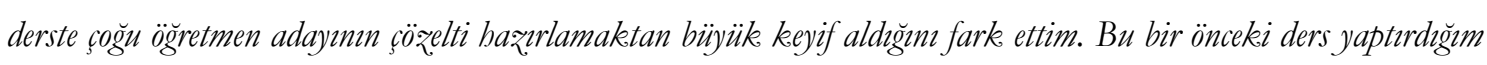
etkinliğg sorgulamama sebep oldu. Belki de bir önceki derste gruplar halinde çözelti hazırlattrrmal, hazurlamıs olduğum etkinliği ise onlara ev ödevi olarak vermeliydim." 


\subsection{Uygulama Sürecini Değerlendirme Anketinden (USDA) Elde Edilen Bulgular}

Uygulama sürecini değerlendirme anketinden elde edilen bulgular öğretmen adaylarının gerçekleştirilen etkinliklere yönelik olumlu ve olumsuz görüşleri olmak üzere iki farklı tabloda sunulmuştur. Tablo 6'da öğretmen adaylarının GKL-1 dersinde gerçekleştirilen yansıtıcı öğretim uygulamalarına yönelik olumlu görüşleri yer almaktadır.

Tablo 6. Öğretmen adaylarının etkinliklere yönelik olumlu görüşleri

\begin{tabular}{|c|c|c|}
\hline Olumlu Görüşler & $\mathbf{F}$ & Alintilar \\
\hline Zevkli & 17 & $\begin{array}{l}\text { Zevkli çükë̈ laboratuvar aletlerine dokunmak, deney yapmak... Hoşuma gidiyor. } \\
\text { (Ö2) }\end{array}$ \\
\hline Eğlenceli & 16 & Derslerde yapılan deney ve grup çalısmalar, eğlenceli hale getiriyor dersi. (Ö15) \\
\hline Faydalı & 14 & $\begin{array}{l}\text { Faydal çünkü bir seyleri ö̈renirken, neyin nereden geldiğini hayatla ilişkilendirip } \\
\text { yorumlayabiliyorsun. (Ö18) }\end{array}$ \\
\hline Verimli & 11 & $\begin{array}{l}\text { Verimli çünkü... Uygulamah olması, dersimizi değisik etkinliklerle süslemek daha } \\
\text { akulda kalıcı hale getiriyor (konuyu)... (Ö6) }\end{array}$ \\
\hline Gerekli & 8 & $\begin{array}{l}\text { Gerekli çünkü... ögretmen adayn olarak, laboratuvarda bilmemiz̧, ögrenmemiz. } \\
\text { (gereken seyler var) ve bazl seylerin alt yapısm olusturmak için bu dersi dinlemek ve } \\
\text { anlamak gerek. (Ö18) }\end{array}$ \\
\hline İlginç & 6 & İlk defa manasiyla deney yaptı̆̆ımı için ilginc geliyor. (Ö15) \\
\hline Kolay & 6 & Kolay çünkü daha önceden gördüğ̈̈müz konular var. (Ö14) \\
\hline Düşündürücü & 5 & $\begin{array}{l}\text { Düşündürücü çünkü bir şeyleri hazırlamadan, yapmadan önce basta nasıl yaparm? } \\
\text { Ne yaparsam ne olur? gibi sorular insanın aklına takılhp düsü̈ndürüyor. (Ö18) }\end{array}$ \\
\hline Harika & 3 & Özellikle deney yapmak harika. (Ö22) \\
\hline
\end{tabular}

Araştırmac1 öğretmenin gözlemleri ve günlügünde tuttuğu notlar da USDA'dan elde edilen verileri destekler niteliktedir. "Malzemeleri tanıyalım" etkinliğini gerçekleştirdikten sonra araştırmacı öğretmenin yazdığ1 günlük notları örnek olarak verilebilir: “..ögretmen adaylar ders sürecinde z̧evkle, aktif olarak çalşstllar ve bunun sonucunda sinf yönetimini sağlamak önceki ynllara göre daha kolay oldu."

Tablo 4'te öğretmen adaylarının GKL-1 dersinde gerçekleştirilen yansıtıcı öğretim uygulamalarına yönelik olumsuz görüşleri yer almaktadır.

Tablo 4. Öğretmen adaylarının etkinliklere yönelik olumsuz görüşleri

\begin{tabular}{|c|c|}
\hline Olumsuz Görüşler & f Alintilar \\
\hline S1kıc1 & $\begin{array}{l}5 \text { Bazen sıkıc buluyorum çünkü yaptığımı boyama çizme etkinliklerinden sıkılıyorum. } \\
\text { (Ö5) }\end{array}$ \\
\hline Gereksiz & $\begin{array}{l}2 \text {...bir poster hazırlamıstık. Bence gereksizdi. O kağıtlar biz okuyup çalısı̨p gelseydik, } \\
\text { siz soru sorduğunuzda cevaplar o şekilde de ögrenebilirdik. (Ö̈7) }\end{array}$ \\
\hline Siradan & 1 Siradan çünkü farkli ve etkileyici deneyler bekliyorum. (Ö17) \\
\hline Zor & 1 ...bazen de zorlaniyorum mesela kimyasal hesaplamalarda. (Ö22) \\
\hline
\end{tabular}

Uygulama sürecini değerlendirme anketinden elde edilen veriler öğretmen adaylarının etkinliklere yönelik nadiren olumsuz görüş bildirdiğini göstermektedir. Ayrıca, uygulama sürecini değerlendirme anketinde yer alan “faydasız”, "korkunç”, "saçma” ve "verimsiz” gibi olumsuz anlam ifade eden kelimeleri işaretleyen öğretmen adayı olmamıştır.

\section{TARTIŞMA}

$\mathrm{Bu}$ çalısma kapsamında genel kimya laboratuvar dersleri yansıtıcı öğretime uygun olarak gerçekleştirilmiştir. Problemin çözümüne yönelik yapılan eylem ile öğretmen adaylarının, daha önceki yıllarda gerçekleştirilen GKL dersleri ile karşılaştırıldığında derse daha aktif katılım göstermeleri ve dersten daha fazla kazanım elde etmeleri sağlanmıştır. Yansıtıcı öğretim ile öğretmen adaylarının kendi kendilerine öğrenmeleri teşvik edilerek, öğrenmelerinden sorumluluk duymaları hedeflenmiştir.

Öğretmen adaylarının etkinlik konularına yönelik öğrenmelerinin etkililiği değerlendirildiğinde laboratuvar malzemelerinin isim ve işlevleri konusunda büyük ölçüde kalıcı ve etkili öğrenme gerçekleştirdikleri görülmektedir. $\mathrm{Bu}$ durumun bu çalışma kapsamında geliştirilmiş ve uygulanmış olan "laboratuvar malzemelerini tanıyalım” etkinliğinin etkililiğinin bir göstergesi olduğu düşünülmektedir. Laboratuvarda güvenlik ile ilgili konunun haftanın ikinci dersinde işlendiği, başarı testinin ise dönem sonunda yapıldığı göz önüne alınırsa laboratuvar güvenliği konusunu öğretmen adaylarının kısmen kalıcı ve etkili bir şekilde öğrendiği söylenebilir. Kırbaşlar, Özsoy-Güneş \& Derelioğlu (2010) fen bilimleri öğretmen adaylarının laboratuvar güvenliği ile ilgili bilgi düzeylerini araştırdıkları çalışmalarında benzer sonuca ulaşmışlardır. Çalışmalara katılan öğretmen adaylarının yarısının laboratuvar güvenliği konusunda başarılı olduğu diğer 
yarısının ise başarısız olduğu tespit edilmiştir. Çalışmada kullanılan "Güvenlik Önlemlerini Öğrenelim”" etkinliği bu ders kapsamında uygulanan ilk etkinliktir. Etkinlik kapsamında kullanılan öğrenme-öğretme yöntemleri öğrencilerin aşina olmadığı yöntemlerdir. Bu konuya yönelik öğrenmenin istenilen düzeyde sağlanamamış olması, öğretmen adaylarının yeni öğrenme-öğretme yöntemlerine henüz adapte olamamış olmaları ve bu sebeple istenilen seviyede derse katılım gösterememiş olmalarından kaynaklanmış olabilir. Bununla birlikte testin son sorusu olan sıvı-sıvı çözeltilerin hazırlanmasına yönelik problem sorusunu hiçbir öğretmen adayı doğru cevaplayamamıştır. Karataş’ın (2016) kimya öğretmen adaylarılla gerçekleştirdiği çalışmadan elde edilen veriler bu çalışmadan elde edilen verileri destekler niteliktedir. Karataş (2016) çalışmasında öğretmen adaylarına belli bir konsantrasyonda çözelti hazırlama görevi vermiştir ve öğretmen adaylarının gerek çözelti hazırlamak için çözeltisi hazırlanacak maddeden alınması gereken miktarı hesaplarken gerekse çözeltiyi hazırlarken birçok hata yaptıklarını tespit etmiştir. Bu ve benzer çalışmalarda (Coştu vd., 2005; Karataş, 2016) çözelti hazırlama ve çözelti hazırlama problemlerine yönelik sorularda öğretmen adaylarının istenilen başarıyı sergileyememesi, bu konular için ayrılmış öğretim süresinin yetersiz kalması, sürenin ve laboratuvar ekipmanlarının yetersiz olmasından ötürü öğretmen adaylarına bireysel olarak çözelti hazırlama firsatı verilememiş olmasından kaynaklanmıș olabilir.

$\mathrm{Bu}$ çalışma kapsamında katı-sıvı ve sıvı-sıvı çözelti hazırlamak için gereken madde miktarının hesaplanması ve çözeltilerin hazırlanması amacıyla iki etkinlik gerçekleştirilmiştir. Başarı testinde ise öğretmen adaylarına yalnızca sıvı-sıvı çözeltilerin hazırlanmasına yönelik bir soru yöneltilmiştir. Bunun sebebi araştırmacı öğretmenin geçmiş deneyimleri doğrultusunda öğretmen adaylarının en çok bu soru tipinde zorlandıklarını belirlemiş olmasıdır. Araştırmacı, bu soruyu doğru cevaplandırabilen öğretmen adaylarının diğer çözelti hazırlama problemleri (katı-sıvı çözeltiler gibi) ile ilgili sorun yaşamayacakları şeklinde bir varsayım yürütmüştür. Bu durum çalışmanın bir sınırlılığı olarak değerlendirilebilir. Farklı bir soru yöneltilmemiş olduğu için öğretmen adaylarının çözelti hazırlama ile ilgili diğer öğrenmeleri açı̆̆a çıkarılamamıştır. Buradan yola çıkılarak, bu çalşmada gerçekleştirilen eylemin, öğretmen adaylarının sıvı-sıvı çözelti problemlerini çözme becerisi kazandırma konusunda kalıcılık sağlamada yeterli gelmediği sonucuna varılabilir. Bu sebeple öğretmen adaylarının sıvı-sıvı çözeltilerin hazırlanması amacıyla alınması gereken madde miktarını hesaplarken yaptıkları hataların analiz edilerek, bu çalışmada geliştirilen çözelti hazırlayalım-1 ve çözelti hazırlayalım-2 etkinliklerinin revize edilmesinin daha etkili öğrenmenin gerçekleşmesinde etkili olacağı düşünülmektedir.

Kimyanın gözle görülmeyen tanecikler ve bunların etkileşimleri ile ilgilenen bir alan olması bu dersi zor kılmakta ve öğrencilerin bu derse yönelik tutumlanını etkilemektedir (Paşa, Bolat \& Karataş, ). Fakat bu çalışmadan elde edilen veriler katılımcıların çoğunun GKL dersini faydalı ve eğlenceli bulduğunu göstermektedir. Az sayıdaki katılımcı ise dersi sıkıcı olarak nitelendirmiştir. Bununla birlikte USDA'da yer alan faydasız, korkunç, saçma ve verimsiz ifadelerini hiçbir katılımcının laboratuvar dersini nitelemek için kullanmadığı belirlenmiştir. Araştırmacı da yansıtıcı öğretime uygun olarak gerçekleştirmiş olduğu dersleri, önceki öğretimleri ile karşılaştırdığında uygulamanın özellikle sınıf yönetimi konusunda kolaylık sağladığını belirtmiştir. Tüm bu veriler yansıtıcı öğretimin sınıf içi dinamiklere olumlu etkileri olarak değerlendirilebilir. Yansıtıc1 uygulamalar laboratuvarda pozitif değişim oluşturma, özellikle öğretmen-öğrenci iletişiminin geliştirilmesi konusunda etkilidir (Towndrow, Ling, \& Venthan, 2008).

\section{SONUÇ ve ÖNERİLER}

Çalışmadan elde edilen veriler doğrultusunda öğretmen adaylarının GKL derslerinde gerçekleştirilmiş yansıtıcı öğretime dayalı etkinliklere yönelik genel olarak olumlu görüşleri olduğu sonucuna varılmıştır. Öğretmen adayları laboratuvar malzemelerini tanıma ve laboratuvarda güvenliğe yönelik daha fazla kalıcı bilgi edinmişken, çözelti hazırlama ve çözelti hazırlama problemleri konusunda istenilen başarıyı sergileyememişlerdir. Öğretmen adaylarının bu konuyu daha iyi özümsemesi amacıyla bu çalışmada kullanılan etkinliklerin elde edilen veriler ışığında revize edilmesi önerilebilir. Bu amaçla öğretmen adaylarına bireysel olarak çözelti hazırlama fırsatı tanınmasının etkili olabileceği düşünülmektedir. Ayrıca öğretmen adaylarının çözelti hazırlama süreçleri videoya kaydedilerek, bu görüntülerin sınıfça izlenip, süreçteki hataların belirlenmesinin öğretmen adaylarının bu konuyu daha iyi anlamalarında etkili olacağı düşünülmektedir. Ayrıca 
öğretmen adaylarının çözelti hazırlama problemlerini çözme süreçlerinin incelenerek, nerelerde hatalar yaptıklarının belirlenmesini sağlayacak mikro düzey çalısmalar konu ile ilgili etkinliklerin geliştirilmesine katkı sağlayabilir.

\section{KAYNAKÇA}

Aksoy, N. (2003). Eylem araştırması: Eğitimsel uygulamaları iyileştirme ve değiştirmede kullanılacak bir yöntem. Kuram ve Uygulamada Egitim Yönetimi Dergisi, 9(4), 474-489.

Aslan, A. (2015). Etkileşimli sınıf dışı kimya ortamı tasarımı ve etkililiğinin değerlendirilmesi. Yayınlanmamış doktora tezi, Karadeniz Teknik Üniveristesi, Trabzon.

Cengiz, C. (2014). Fen bilgisi öğretmen adaylarının genel kimya laboratuvarı dersinde hazırladıkları yansıtıcı günlüklerin yansıtıcı düşünme ve akademik başarıları üzerine etkisi. Yayınlanmamış doktora tezi, Karadeniz Teknik Üniversitesi, Trabzon.

Collins, A., \& Spiegel, S. A. (1995). So you want to do action research? http://www.chem.fsu.edu/ gilmer/PDFs/Action\%20research Science\%20FEAT\%20teachers.pdf\#p age $=77$. Adresinden 1.12.2016 tarihinde edinilmiştir.

Coştu, B., Ayas, A., Çalık, M., Ünal, S. \& Karataş, F. Ö. (2005). Determining preservice science teachers' competencies in preparing solution an in use of laboratory tools. Hacettepe University Journal of Education, 28, 65-72.

Ersözlü, Z. N. \& Arslan, M. (2009). The effect of developing reflective thinking on metacognitional awareness at primary education level in Turkey. Reflective Practice, 10(5), 683-695.

Ertmer, P. A., \& Newby, T. J. (1996). The expert learner: Strategic, self-regulated, and reflective. Instructional science, 24(1), 1-24.

Feyzioğlu, B., Demirdağ, B., Ateş, A., Çobanoğlu, İ. \& Altun, E. (2011). Kimya öğretmenlerinin laboratuvar uygulamalarına yönelik algıları: İzmir ili örneği. Kuram ve Uygulamada Eğitim Bilimleri Dergisi, 11(2), 10051029.

Gündoğan Çögenli, A., \& Güven, M. (2014). Bilişüstü öğrenme stratejileri belirleme ölçeğinin geçerlik ve güvenirlik çalıs̆ması. Dicle Üniversitesi Ziya Gökalp Eğitim Fakültesi Dergisi, 22, 283-297.

Hatton, N. \& Smith, D. (1995). Reflection in teacher education: Towards definition and implementation. Teacbing and Teacher Education, 11, 33-49.

Herrington, D. G., \& Nakhleh, M. B. (2003). What defines effective chemistry laboratory instruction? Teaching assistant and student perspectives. Journal of Chemical Education Research, 80(10), 1197.

Hofstein, A. (2004). The laboratory in chemistry education: Thirty years of experience with developments, implementation, and research. Chemistry Education Research and Practice, 5(3), 247-264.

Karataş, F. Ö. (2016). Pre-service chemistry teachers' competencies in the laboratory: A cross-grade study in solution preparation. Chemistry Education Research and Practice, 17(1), 100-110.

Kırbașlar, F. G., Güneș, Z. Ö., \& Derelioğlu, Y. (2010). Fen bilgisi öğretmen adaylarının laboratuvar güvenliği konusuna yönelik düşünce ve bilgi düzeylerinin araştırılması. Gaæi Üniversitesi Gað̧i Eğitim Fakültesi Dergisi, 30(3).

Kocakülah, A. \& Savaş, E. (2011). Fen bilgisi öğretmen adaylarının deney tasarlama ve uygulama sürecine ilişkin görüşleri. Ondokuz Mayıs Üniversitesi Ë̆itim Fakültesi Dergisi, 30(1), 1-28.

Nakhleh, M. B. (1994). Chemical education research in the laboratory environment: How can research uncover what students are learning?

Özdem, Y., Ertepınar, H., Çakıroğlu, J. \& Erduran, S. (2013). The nature of pre-service science teachers' argumentation in inquiry-oriented laboratory context. International Journal of Science Education, 35(15), 25592586.

Özsoy, G. (2008). Üstbiliş. Türk Eğitim Bilimleri Dergisi, 6(4), 713-740.

Paşa, S., Bolat, Y. ve Karataş, F. Ö. (2015). Kimya Öğretmenliği Öğrencilerinin Bilişim Teknolojilerine Yönelik Tutum Ve Görüşlerindeki Değişimler: Chembıodraw Uygulaması. Journal of Computer and Education Research, 3(6), 71-98.

Rickey, D., \& Stacy, A. M. (2000). The role of metacognition in learning chemistry. J. Chem. Educ, 77(7), 915.

Senemoğlu, N. (2012). Gelişim, öğrenme ve öğretim kuramdan uygulamaya (21. baskı). Ankara: Pegem A Yayıncilik.

Towndrow, P. A., Ling, T. A., \& Venthan, A. M. (2008). Promoting inquiry through science reflective journal writing. Eurasia Journal of Mathematics, Science \& Technology Education, 4(3), 279-283.

URL-1, https://www.youtube.com/watch?v=XIsznZR4hzY. What is reflective learning? 05.05.2016

Ürey, M. \& Aydın, M. (2014). Genel biyoloji laboratuvarı kapsamında geliștirilen bio-lab-web yönteminin etkililiği ve öğretmen adaylarının görüşleri. Dicle Üniversitesi Ziya Gökalp Eğitim Fakültesi Dergisi, 22, 150167. 
Wilson, J. \& Jan, L.W. (1993). Thinking for themselves: Developing strategies for reflective learning. Australia: Eleanor Curtain Publishing.

Winter, R. \& Munn-Giddings, C. (2002). A handbook for action research in health and social care. London: Routledge.

Zuber-Skerritt, O. (1992). Action Research in Higher Education: Examples and Reflections. Kogan Page Limited, 120 Pentonville Road, London N1 9JN England, United Kingdom.

\section{Citation Information}

Cengiz, C. (2017). Fen Bilgisi Öğretmen Adaylarının Genel Kimya Laboratuvarı Dersinde Aktif Öğrenmelerini Sağlamaya Yönelik Bir Eylem Araştırması. Dicle Üniversitesi Ziya Gökalp Eğitim Fakültesi Dergisi, 30, 574-587. 


\section{EK 1}

\section{Uygulama Sürecini Değerlendirme Anketi}

Şimdiye kadar Genel Kimya Laboratuvar1-I dersinde gerçekleştirdiğimiz etkinlikleri göz önünde bulundurduğunuzda, bu dersleri aşağıdaki kelimelerden hangileri ile tanımlayabilirsiniz. Lütfen yuvarlak içerisine alarak işaretleyiniz ve bu kelimeleri kimya laboratuvarı dersiyle örtüştürmenizin sebebini ayrıntılı olarak açıklayınız.

Ayrıca aşağıdaki kutuda bulunan kelimelerin dışında sizin kimya laboratuvarı dersi ile ilişkilendirdiğiniz başka kelime/kelimeler varsa kutu içerisine ekleyiniz ve onları da yuvarlak içerisine alarak işaretleyiniz.

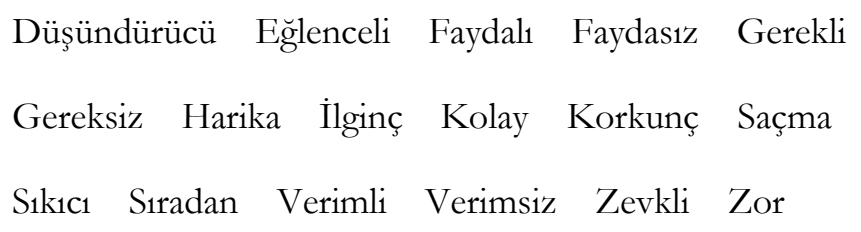

Bu kelimeleri seçmenizin sebebini açılayınız: 


\section{EK 2}

\section{Başarı Testi}

1. Laboratuvar ortamında çalışanların sağlık ve güvenliği için temel güvenlik kurallarına uyulması büyük önem taşımaktadır. Aşağıda laboratuvarda uyulması gereken temel güvenlik kurallarından bazıları ile ilgili kısa notlar verilmiştir. Lütfen her bir notun yanına detaylı açıklamasını yazınız.

a. Derişik asitlerin seyreltilmesi konusunda dikkat edilmesi gereken bazı hususlar vardır:

b. Deney tüplerinin bek alevinde 1sıstılması sürecinde dikkat edilmesi gereken bazı hususlar vardir:

c. Civa herhangi bir şekilde dökülürse vakum kaynağı ya da köpük tipi sentetik süngerlerle toplanmalıdır. Eğer toplanamayacak kadar eser miktarda ise:

d. Benzin, eter ve karbon sülfür gibi bazı maddeler ortak bir özelliklerinden ötürü laboratuvarda tehlike yaratabilirler, bu sebeple bu maddelerin bulunduğu ortamda şuna dikkat edilmelidir:

2. Aşağıda isimleri verilen laboratuvar malzemelerinin şekillerini çizerek kullanım amaçlarını açıklayınız.
a. Mezür,
b. Balon joje,
c. Geri soğutucu,
d. Spatül,
e. Baget
f. Puar

3. Yoğunluğu 1,15g/ml olan ağırlıkça \% 00 ’lik $\mathrm{CH}_{3} \mathrm{COOH}$ çözeltisini kullanarak,

a. $\quad$,1M $100 \mathrm{ml} \mathrm{CH} \mathrm{CHOH}_{3} \mathrm{ÇÖzeltisi} \mathrm{hazırlamak} \mathrm{için} \mathrm{gerekli} \mathrm{hesaplamaları} \mathrm{yapınız} \mathrm{(MA} \mathrm{CH}{ }_{3} \mathrm{COOH}$ : $60 \mathrm{~g} / \mathrm{mol})$.

b. Çözeltinin hazırlanması için gereken basamaklanı, bu süreçte kullanılan malzemeleri de belirterek adım adım yazınız. 